\title{
Akt założycielski polskiego strukturalizmu immanentnego: Juliusza Kleinera Treść i forma w poezji
}

\begin{abstract}
Obremski Krzysztof, Akt założycielski polskiego strukturalizmu immanentnego: Juliusza Kleinera Treść i forma w poezji [The Founding Act of Polish Immanent Structuralism: Juliusz Kleiner's Content and Form in Poetry]. "Przestrzenie Teorii" 35. Poznań 2021, Adam Mickiewicz University Press, pp. 125-137. ISSN 1644-6763. DOI 10.14746/pt.2021.35.5.

In Polish literary studies methodology, Kleiner's status as entirely marginal, if not anachronistic, can be justified only on one condition, namely if we overlook the study Content and form in poetry ("Przegląd Warszawski" 1922, r. 2, vol. 2, pp. 323-333), for it can be read as the rejected cornerstone of Polish immanent structuralism. Due to the ambiguity of the term "structuralism", it is necessary to define its meaning here: it will be determined by the historical context, i.e. the Course in General Linguistics (first edition: 1916). Adopting Janusz Sławiński's terminology, we may add that it is a rejected cornerstone of immanent ("unconscious") structuralism, not a formulated one.
\end{abstract}

KEYWORDS: Juliusz Kleiner, content, form, structuralism

[...] na dobra sprawę każdy, kto zajmowat się budowq dzieła literackiego, Witkacy $i$ Kleiner, Ingarden i Konrad Górski, był w pewnym sensie semiotykiem.

Henryk Markiewicz, Pytania do semiotyków (literatury) ${ }^{1}$

Znamienne: wziąwszy do ręki (licząca nieco ponad pięćset stron) monografię problemową Strukturalizm w Europie środkowej i wschodniej. Wizje i rewizje, znajdziemy Juliusza Kleinera wyłącznie jako postać marginalna, a więc jedynie wzmiankowaną w kontekście Pozytywizmu Kazimierza Dominika Wóycickiego (trzykrotnie) oraz Powstania i rozwoju szkoły badawczej Manfreda Kridla (jednokrotnie). Treść i forma w poezji? Daremnie szukać nawet samego tytułu. To może wydawać się wręcz oczywiste, wszak trzy klasyczne monografie romantycznych wieszczów przesłoniły Treść i forme $w$ poezji (ponadto jeszcze poniekąd zabójcza fraza „Słowacki wielkim poetą był!" miała i wciąż zachowuje coś z literaturoznawczego wykluczenia). Jednak w polskiej metodologii badań literackich jeśli już nie anachroniczny, to przynajmniej wyłącznie marginalny status Kleinera może być uza-

${ }^{1}$ H. Markiewicz, Pytania do semiotyków (literatury), [w:] tegoż, Literaturoznawstwo i jego sqsiedztwa, Warszawa 1989, s. 169. 
sadniony tylko pod jednym warunkiem, mianowicie przejścia do porządku nad studium Treść $i$ forma $w$ poezji („Przegląd Warszawski” 1922, r. 2, t. 2, s. 323-333). Ono bowiem może być czytane niczym akt założycielski polskiego strukturalizmu immanentnego. Zważywszy wieloznaczność terminu „strukturalizm”2, należy dookreślić jego tu przyjmowane znaczenie: będzie ono zdeterminowane kontekstem historycznym, a więc Kursem językoznawstwa ogólnego (pierwodruk: 1916). Podjąwszy terminologię Janusza Sławińskiego, jeszcze dopowiedzmy: strukturalizmu immanentnego (,nieświadomego"3).

Czy zawarta w tytułowych słowach tej publikacji ocena - akt założycielski polskiego strukturalizmu immanentnego - jest zawyżona? Odpowiedź brzmi przeczacco, ponieważ Treść $i$ forma $w$ poezji to studium, którego autor zanim podją zasadniczy problem struktury dzieła literackiego, wcześniej stał się ojcem założycielem polskiej teorii literatury:

[W rozprawie Charakter i przedmiot badań literackich (1913)] Wyosobniwszy dwa plany badań: historię literatury i systematykę literatury, dołącza do nich J. Kleiner [...] ich dziedzinę trzecią. Jest nią te oria liter atury. Trzeba stwierdzić, że owo - prawie doczepione do rozprawy - wprowadzenie w horyzonty nauki o literaturze teorii literatury, jest właściwie jej aktem instauracyjnym, przynajmniej w Polsce. Nie dlatego, aby dotąd nie było prac w tej dziedzinie, ale dlatego, że bodaj po raz pierwszy z taką jasnością została postawiona sprawa samoistności badań teoretycznoliterackich i obdarzona po raz pierwszy odrębną a właściwa nazwa. [...] Dopiero ustalona, czy zaakceptowana przez J. Kleinera nazwa teorii literatury nie zostawiała wątpliwości co do zasięgu przedmiotu jej badańn 4 .

2 „Od wyrazu struktura pochodzi termin »strukturalizm«. Jest on używany w dzisiejszej humanistyce [pisane jeszcze w pierwszej połowie lat osiemdziesiątych - przyp. K.O.] co najmniej w czterech różnych znaczeniach; bywają one często ze sobą mieszane, co powoduje liczne nieporozumienia”. A. Weinsberg, Językoznawstwo ogólne, Warszawa 1983, s. 20. Inne uporządkowanie zjawisk obejmowanych terminem „strukturalizm”: A. Burzyńska, M.P. Markowski, Teorie literatury XX wieku. Podręcznik, Kraków 2007, s. 199-200. Jeszcze inna publikacja, przywołana wyłącznie przykładowo (a nie z myślą o wyczerpującej bibliografii): B. Szymańska, Co to jest strukturalizm?, Kraków 1980.

${ }_{3}^{3}$ „Warto też pamiętać, że »ojciec« strukturalizmu - Ferdinand de Saussure - w ogóle nie posługiwał się pojęciem »struktury" (Georges Mounin nazwał go nawet »le structuraliste sans le savoir - "strukturalistą nieświadomym«). Jednakże de Saussure'owskie ujęcie języka jako systemu pokrywało się dokładnie z tym, co należało rozumieć pod pojęciem struktury, w takiej formie, w jakiej pojawiło się ono na gruncie strukturalizmu, i dlatego ten właśnie termin przyjął się, dając nazwę całemu kierunkowi”. A. Burzyńska, M.P. Markowski, dz. cyt., s. 203.

${ }^{4}$ S. Skwarczyńska, Juliusz Kleiner jako metodolog i teoretyk literatury, [w:] Juliusz Kleiner. Księga zbiorowa o życiu i działalności, red. F. Araszkiewicz, Lublin 1961, s. 61; podkr. K.O.; oryginalna interpunkcja zachowana. Ówcześnie o artykule Charakter i przedmiot badań literackich napisano, że stanowił on „punkt zwrotny w dziejach polskiej metodologii 
Z kolei Treść $i$ forma $w$ poezji z 1922 roku nakazuje wskazać założycielski status tej publikacji - uwarunkowany początkiem lat dwudziestych: nieco wcześniej (1920? 1921?) w Pradze pojawił się Roman Jakobson, w 1926 roku zostało założone Praskie Koło Lingwistyczne. Manfreda Kridla Wstęp do badań nad dzietem literackim 5 to już 1936 rok.

Jeszcze na przełomie lat pięćdziesiątych i sześćdziesiątych poprzedniego stulecia Stefania Skwarczyńska (za nia przyjmijmy poszerzone znaczenie „poezji”: rozumianej jako dzieła literackie) wskazała na to, co można przyjąć jako wstępną przesłankę strukturalizmu immanentnego w studium Treść $i$ forma $w$ poezji, mianowicie „treść” i „forma” sa konstytuowane ich relacjami. Te co prawda były przez Kleinera przedstawione w perspektywie stanowionej procesem twórczym, to jednak nie musi znaczyć, że psychogenetyczny status składników dzieła literackiego zamyka je w diachronii - wszak zwieńczeniem procesu twórczego będzie finalny porządek synchroniczny (między innymi Janusza Sławińskiego Synchronia i diachronia w procesie historycznoliterackim dowodzi, że równoczesność i następstwo czasowe mogą być komplementarne). Jeśli Kleiner rekonstruował proces twórczy to przecież także w tym celu, aby unaocznić, jakie będzie dzieło literackie w jego finalnej postaci. Treść $i$ forma $w$ poezji to nie psychogenetyzm samoistny, lecz zwieńczony odsłonięciem synchronicznej struktury zasadniczego przedmiotu badań literackich: pojedynczego utworu.

Kiedy czytamy Juliusz Kleiner jako metodolog i teoretyk literatury, wówczas znajdziemy „organiczny charakter dzieła literackiego”, jego „wewnętrzna jedność", ale (nawet jedynie immanentny) strukturalizm studium z 1922 roku może wydawać się przekreślony:

Skoro wyrazem jest dzieło literackie, to - nawet gdyby zmatować twierdzenie o jego erupcyjnym charakterze - ów wyraz musi stanowić jednolita, niepodzielna całość. A w takim razie traci sens doszukiwanie się w nim „czynników składowych”, czy warstw nakładających się na siebie. Zostaje natomiast eksponowany proces twórczy, w toku którego zalążek treściowy rozwinie się w utwór w jego ostatecznej postaci. Kategorie czasowe - kwestia faz rozwojowych - zastapia widzenie dzieła w kategoriach quasi-przestrzennych. Trzeba o tym pamiętać, aby należycie uchwy-

literackiej” (K. Górski, Przeglad stanowisk metodologicznych w polskiej historii literatury do 1939 r., [w:] K. Górski, Z historii i teorii literatury, Seria Druga, Warszawa 1964, s. 48).

${ }^{5}$, „[...] doszło w drugim dziesięcioleciu międzywojennym do wariantowych "przeszczepów“ rosyjskiej szkoły formalnej. Takim wariantowym "przeszczepem« była niewątpliwie "polska szkoła formalna", mniej od rosyjskiej radykalna w formalizmie, jeśli za jej naukowy manifest poczytać M. Kridla Wstęp do badań nad dzietem literackim (1936)”. S. Skwarczyńska, Kierunki $w$ badaniach literackich, Warszawa 1984, s. 277. Por. A.F. Kola, Powstanie i rozwój szkoty badawczej Manfreda Kridla. Rola aktorów poza-ludzkich, [w:] Strukturalizm w Europie Środkowej i Wschodniej. Wizje i rewizje, red. D. Ulicka, W. Bolecki, Warszawa 2012, s. 188-199. 
cić całe dowodzenie Kleinera dotyczące treści i formy w dziele literackim, pojętym jako organiczna całość ${ }^{6}$.

Właśnie, strukturalizm immanentny studium z 1922 roku wyłącznie może wydawać się przekreślony, gdyż

a) z miejsca (tzn. niewiele dalej po tu zacytowanym fragmencie) jednak znajdziemy przynajmniej pogłos strukturalizmu za sprawą pojawienia się dlań zasadniczego terminu:

Wziąwszy pod uwagę idealny schemat rozwoju wewnętrznego dzieła, a więc 1. zalążkową treść istotna, 2. koncepcję, 3. struk t u r ę, 4. formę zewnętrzną - [Kleiner] stwierdza, że tylko „faza pierwsza” reprezentuje czystą treść, a „ostatnia” czysta formę ${ }^{7}$.

(oczywiście „struktura” automatycznie o czymkolwiek nie rozstrzyga i nikogo strukturalista nie czyni, choćby z tego powodu, że słowo to zostało odnotowane nawet w ,Słowniku polszczyzny XVI wieku”);

b) skoro w poświęconym treści i formie wywodzie Kleinera dzieło literackie było „pojęte jako organiczna całość”, to niejako tym samym będzie ono pojmowane strukturalistycznie, gdyz: ,pojęcie struktury wywodzi się z teorii organizmu - jako układu elementów nastawionego na wypełnianie zadań życiowych”. Tak więc twierdzenie Stefanii Skwarczyńskiej: „Kategorie czasowe - kwestia faz rozwojowych - zastapia widzenie dzieła w kategoriach quasi-przestrzennych" po części zostało zakwestionowane następującym po nim zdaniem; można powiedzieć, że dla strukturalizmu znamienne „kategorie quasi-przestrzenne" stały się przedmiotem zaprzeczenia i... z miejsca powróciły - już jako „organiczna całość”.

Problem zasadniczy dla dostrzeżenia aktu założycielskiego polskiego strukturalizmu immanentnego to relacja między diachronia a synchronia. Analogicznie jak Stefania Skwarczyńska twierdził Artur Hutnikiewicz:

${ }^{6}$ S. Skwarczyńska, Juliusz Kleiner jako metodolog i teoretyk literatury..., s. 65-66.

7 Tamże, s. 66; podkr. K.O.

${ }^{8}$ Z. Mitosek, Teorie badań literackich. Przeglad historyczny, Warszawa 1983, s. 211. Obawa przed wyrwaniem cytatu z kontekstu nakazuje przywołać cały passus: „Jedną z cech dwudziestowiecznego myślenia jest przewartościowanie związków przyczynowo-skutkowych na korzyść ujmowania zjawisk jako elementów pewnych całości, w ich równoczesności i wzajemnym sprzężeniu. Pojęcie funkcji wypiera kategorię genezy. Przedmioty nakierowane na spełnianie określonych funkcji bada się jako celowe układy elementów, które zyskują znaczenie w relacji do struktury całości, z kolei struktura rysuje się jako sieć stosunków pomiędzy elementami. Struktura więc jest porządkiem przedmiotu; sam przedmiot może być rozumiany szeroko, jako osobowość, obrzęd religijny, stosunki społeczne epoki czy dzieło sztuki. Tak rozumiane pojęcie struktury wywodzi się z teorii organizmu - jako układu elementów nastawionego na wypełnianie zadań życiowych. [...]”. Tamże. 
„Będąc wyrazem, objawia się ono [dzieło] jako całość, a nie suma elementów składowych. Jako proces twórczy, a nie przedmiot istniejący o strukturze niby-przestrzennej”’ Mniejsza tu o podłoże tegoż podwojonego odżegnywania się od niby-przestrzeni (nawet wbrew czterem jakże ważnym właśnie przestrzennym schematom $\mathrm{w}$ studium Kleinera!), gdyż przypuszczenia niejako siłą rzeczy mogą stawać się pomówieniami (przejście do porządku nad przecież autorskimi schematami w studium Kleinera byłoby uwarunkowane pragnieniem Skwarczyńskiej oraz Hutnikiewicza, aby Treść i formę $w$ poezji niejako zamknać $\mathrm{w}$ jeszcze przed-strukturalistycznej teorii literatury?).

Najogólniejsze pytanie brzmi: czy diachronia procesu twórczego zawiesza bądź nawet przekreśla synchroniczny status dzieła literackiego? Ad fontes! A więc: przede wszystkim Treść $i$ forma $w$ poezji. Z jednej strony Kleiner, wyróżniwszy cztery „stadia rzeczywiste czy przypuszczalne procesu twórczego"10, wyeksponował diachroniczność. Zarazem wskazał synchroniczny status dzieła literackiego, zwerbalizowany jakże dlań istotnym terminem „warstwy” oraz tym twierdzeniem: „Ale skoro forma D zadowoliła już poetę, dochodzi do zrośnięcia się warstw wszystkich i [wytworzone procesem twórczym - przyp. K.O.] granice zacierają się dla świadomości"11. Diachronia procesu twórczego prowadziła Kleinera do wieńczącej ją synchronii dzieła literackiego: „Ponieważ proces twórczy jest syntetyczny, więc tylko w ciąu jego trwania ta różność [treści i formy - przyp. K.O.] jest czymś aktualnym jego ukończenie jest zarazem zatarciem owej różności" ${ }^{2}$. Niczym ważny punkt manifestu strukturalizmu immanentnego może zabrzmieć to twierdzenie: „»Treść« i »forma« nie oznaczają grup odrębnych wśród składników dzieła, lecz stosunki wzajemne"13. Przecież (z czasem już sformułowany) strukturalizm nie poprzestawał na samym wyróżnianiu elementów współtworzących dzieło literackie, te bowiem dlań pozostawały tylko materią badań zasadniczych: relacji między elementami. Innymi słowy: z jednej strony Kleiner (ówcześnie w trybie nieuniknionym obciążony psychogenetyzmem?) bezdyskusyjnie jakby przechylił się w stronę diachronii procesu twórczego, ale zarazem temuż może być przeciwstawiona finalna synchronia dzieła literackiego. Toteż zamiast o ich przeciwieństwach należy mówić o sprzężeniu zwrotnym oraz koniunkcji: panchronii. Ta skąd jednak pochodziła?

${ }^{9}$ A. Hutnikiewicz, Stowo wstęne, [w:] J. Kleiner, W kregu historii i teorii literatury, wybór, oprac. A. Hutnikiewicz, Warszawa 1981, s. 19.

${ }^{10} \mathrm{~J}$. Kleiner, Treść i forma $w$ poezji, [w:] J. Kleiner, W kręgu historii i teorii literatury, wybór, oprac. A. Hutnikiewicz, Warszawa 1981, s. 607.

${ }^{11}$ Tamże, s. 611.

12 Tamże, s. 612.

${ }^{13}$ Tamże, s. 616. 
Dla Kleinera lata 1910-1911 to czas studiów w Paryżu (Collége de France i École des Hautes Études). „[...] wydaje się, iż zetknięcie się z A. Meilletem otworzyło przed nim obraz związków pomiędzy językoznawstwem a badaniami literackimi [...]"14. Tenże francuski językoznawca w młodości był słuchaczem wykładów de Saussure’a w Paryżu, zanim ów w 1891 roku przeniósł się do Genewy. „W wiele lat później, po ukazaniu się drukiem Kursu językoznawstwa ogólnego de Saussure'a [pierwsze wydanie: 1916; wydanie drugie poprawione: 1922] Meillet w swojej recenzji z Kursu napisze, że de Saussure już wówczas wykazywał zainteresowania ogólnojęzykoznawcze"15. Może nawet więzi, a przynajmniej wspólnoty myśli czy chociażby znajomości obydwu językoznawców dowodzi to, że po śmierci autora Kur$s u$... (tu pomińmy role słuchaczy wykładów oraz redaktorów drukowanych publikacji) autorem nekrologu w „Bulletin de la Sociéte de Linguistique de Paris" był właśnie Antoine Meillet.

Jeśli Treść $i$ forma $w$ poezji może być czytana w kontekście założycielskich dla strukturalizmu wykładów genewskich, to przede wszystkim za sprawą 1) tego, co jest nazwane panchronią oraz 2) relacyjnej materii dzieła literackiego.

[Ad. 1:] Prawda synchroniczna wydaje się zaprzeczeniem prawdy diachronicznej i patrząc na rzeczy powierzchownie, wyobrażamy sobie, że musimy wybrać między nimi; w rzeczywistości nie jest to wcale konieczne; jedna z tych prawd nie wyklucza bynajmniej drugiej ${ }^{16}$.

[Ad. 2:] To, co znajduje się w znaku z pojęcia lub z materiału językowego, ma mniejsze znaczenie niż to, co znajduje się wokół niego w innych znakach. [...]

Jednostka i fakt gramatyczny nie utożsamiałyby się, gdyby znaki językowe polegały na czymś innym niż na różnicach. Wobec tego jednak, ze język jest tym, czym jest, z którejkolwiek strony będziemy go rozpatrywać, nie znajdziemy w nim niczego prostego; zawsze i wszędzie będzie to ta sama złożona równowaga składników warunkujacych się wzajemnie ${ }^{17}$.

Podobnie postępował Kleiner: każda spośród przez niego wyróżnionych warstw dzieła literackiego została ukonstytuowana jej binarnymi relacjami z innymi (Treść - Forma; Treść istotna - Koncepcja lub kształt - Struk-

${ }^{14}$ S. Skwarczyńska, Juliusz Kleiner jako metodolog i teoretyk literatury..., s. 53.

${ }^{15}$ K. Polański, Wprowadzenie, [w:] F. de Saussure, Kurs językoznawstwa ogólnego, przekł. K. Kasprzyk, wstęp i przypisy K. Polański, Warszawa 2002, s. 6.

${ }^{16}$ F. de Saussure, dz. cyt., s. 119.

${ }_{17}$ Tamże, s. 143-146. „De Saussure podkreśla, że żadnego faktu językowego nie da się zdefiniować w samym sobie. Skoro bowiem znak językowy ma charakter arbitralny, to jest bytem czysto relacyjnym i dlatego, aby zidentyfikować znaki, należy się uciec do systemu relacji i różnic, które je tworzą". K. Polański, dz. cyt., s. 13-14. 
tura - Forma zewnętrzna lub wyraz ostateczny). Relacyjna materia dzieła literackiego konsekwentnie pozostawała 'głębinowa', ale przynajmniej raz była przedstawiona 'powierzchniowo': „Może zaliczenie pewnych elementów [treści oraz formy - przyp. K.O.] do zakresu jednego lub drugiego pojęcia nie od istoty pierwiastków zależy, lecz od zajętego wobec nich [przez badacza - przyp. K.O.] stanowiska?" ${ }^{18}$. Takie pytanie Kleiner zwerbalizował w pierwszej części aktu założycielskiego strukturalizmu immanentnego odpowiedź twierdząca przyniosły dalsze strony, ale z jednym dyskusyjnym wyjątkiem: mianowicie chociaż warstwa pierwsza schematu „nie jest forma dla żadnej innej treści, czyli nie podpada pod pojęcie formy"19, to przecież może współtworzyć dwie nierównorzędne opozycje, gdyż:

Wspomnieć należy, że psychoanalityk dodałby do schematu jeszcze warstwę A i uważałby już warstwę A za formę dla owej warstwy pierwotnej, będącej treścią podświadoma. Ale takie postawienie kwestii nie zmieniłoby istoty schematu: zawsze będzie w nim warstwa pierwsza, która jest tylko treścią i nie może być traktowana jako forma innej warstwy ${ }^{20}$.

W czasie o stulecie późniejszym od 1922 roku słowa te można czytać w dwojakiej perspektywie: wcześniej, jeszcze w pierwszych latach XX wieku, powstała Pałuba z jej narratologiczna materią kilka dekad później Jacques Lacan orzeknie: „Nieświadomość ustrukturowana jest jak język”21.

Treść i forma w poezji jako wypowiedź teoretycznoliteracka wyróżnia się tym, że autorski wywód został - dosłownie - unaoczniony czterema schematami. Te ówcześnie w publikacjach literaturoznawczych pozostawały czymś co najwyżej sporadycznym. Skąd więc pochodzą? I Skwarczyńska, i Hutnikiewicz tego pytania nie podjęli. Odpowiedź zapewne może być jedynie hipotetyczna i taka pozostać musi, jednak nawet świadomość względności przeciwstawiania interpretacji i nadinterpretacji nie powstrzyma piszącego te słowa przed wskazaniem Kursu... Powtórzę: jego pierwsze wydanie to 1916 rok; wydanie drugie poprawione - 1922 rok. Niezależnie od tego, w jakim zakresie słuchacze oraz redaktorzy założycielskich dla strukturalizmu wykładów genewskich byli współautorami ilustracji, te pozostaja czymś bezdyskusyjnym. Oczywiście rzecz intertekstualna zawiera się nie w kopiowaniu ich czy w innych, bardziej pośrednich zależnościach, lecz wyłącznie w inspiracji: podążywszy za de Saussure'em, Kleiner słowo pisane może nawet splótł z jedynie schematycznymi przedstawieniami naocznymi.

\footnotetext{
${ }^{18}$ J. Kleiner, Treść $i$ forma $w$ poezji..., s. 607.

19 Tamże, s. 613.

${ }^{20}$ Tamże, s. 613, przyp. 11.

${ }^{21}$ Cyt. za: A. Burzyńska, M.P. Markowski, dz. cyt., s. 45.
} 
Szczególnie finalny schemat ${ }^{22}$ może być kojarzony z tym, który znajdowali czytelnicy genewskich wykładów ${ }^{23}$ :
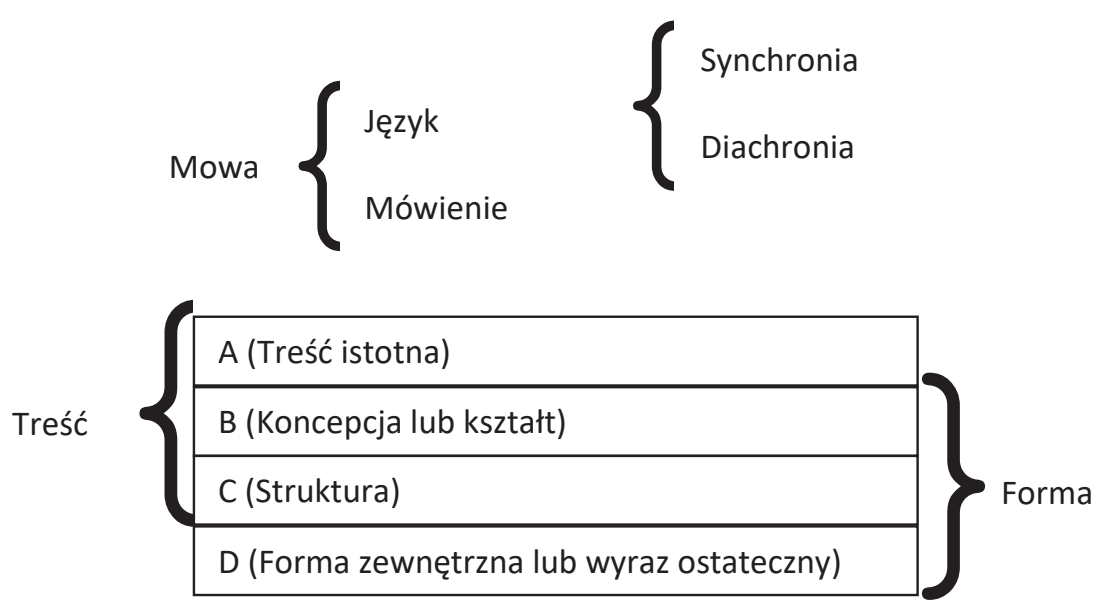

Za hipoteza, że Treść i forma w poezji przynajmniej po części prawdopodobnie były zainspirowane Kursem..., może dodatkowo przemawiać ówczesny, to znaczy w Polsce lat dwudziestych, status genewskiego „prawodawcy strukturalizmu"24.

Czy Treść $i$ forma $w$ poezji faktycznie pozwala mówić o akcie założycielskim polskiego strukturalizmu immanentnego? Wyłącznie marginalny status owej publikacji we współczesnych, tzn. o stulecie późniejszych, tekstach teoretycznoliterackich wydaje się bezdyskusyjny. Nawet jeśli Kleinera znajomość Kursu... pozostawała jedynie pośrednia (medium byłby

${ }^{22}$ J. Kleiner, Treść $i$ forma $w$ poezji..., s. 613.

${ }^{23}$ F. de Saussure, dz. cyt., s. 122.

${ }^{24}$ „O tym, że presję prestiżu, jakim cieszyło się nazwisko nominalnego autora Kursu..., dało się odczuć także w Polsce, i to już w latach dwudziestych, świadczy notka bibliograficzna, którą Witold Doroszewski opatrzył swój artykuł „Język” a „mówienie”. Warto dodać, że choć polski językoznawca wypomina prawodawcy strukturalizmu pewne braki i niejednoznaczności w podstawowych definicjach, jego polemika nie należy do szczególnie ostrych, a ocena nie jest jednoznacznie negatywna.

Artykuł niniejszy przesłałem w r. 1928 do Redakcji Biuletynu PTJ [Polskie Towarzystwo Językoznawcze - A.S.-P.] w Krakowie. Otrzymałem odpowiedź, że ogłaszanie krytyki tak uznanego autorytetu jak de Saussure postawiłoby Redakcję w sytuacji niezręcznej.

Mimo że rzeczony artykuł ukazał się gdzie indziej już w następnym roku, ten przykład swoistej cenzury wydawniczej uczula na wszelkie pozamerytoryczne uwarunkowania recepcji teorii de Saussure'a. Uczula tym bardziej, że stosunek do niej stał się w niektórych ujęciach narzędziem klasyfikacji oraz miernikiem wartości późniejszych dokonań lingwistycznych (a także literaturoznawczych czy filozoficznych)". A. Skubaczewska-Pniewska, W więzieniu systemu. Ferdinand de Saussure a teoria literatury, Torun 2013, s. 11-12. 
Meillet?!) i o prostym związku przyczynowo-skutkowym niepodobna mówić, to przecież jego postawa strukturalistyczna była wyraźna i o tym przecież nie rozstrzyga sama obecność słowa „struktura” - o kilka lat wcześniejsza niż w badaniach Praskiego Koła Lingwistycznego ${ }^{25}$ !

Pamiętając o płynnej (może nawet woluntarystycznej?) granicy między interpretacją a nadinterpretacja jednak można odważyć się na wskazanie analogii: Treść $i$ forma $w$ poezji zawiera ten sam tryb pojmowania dzieła literackiego, jaki dla języka został przyjęty w Kursie... Mianowicie obydwaj, de Saussure i Kleiner, stanęli przed podobnym wyzwaniem doprawdy fundamentalnym: jak zdefiniować język i jak określić, czym jest dzieło literackie? De Saussure w zakresie zjawisk związanych z „mową” (langage) wyróżnił ,język” (langue) i „mówienie” (parole), a więc przeciwstawił abstrakcyjny język mówieniu jako zjawisku jednostkowemu i konkretnemu (tu nie należy skrywać: „Rozróżnienie między językiem a mówieniem nie jest jednak sprawą całkowicie jasną u de Saussure'a”"26). Przynajmniej podobne przeciwstawienie zwerbalizował Kleiner: $\mathrm{w}$ ich postaciach abstrakcyjne „treść” oraz „forma” współtworzą przeciwieństwo pojedynczych i konkretnych dzieł literackich. Wyłania się analogia: jak ,język” ma się do „mówienia”, tak „treść” i „forma” do dzieł literackich. Być może jednak dla unaocznienia relacji wiążących Kleinera z de Saussure'em oraz Meillet'em najtrafniejsza byłaby formuła, jaka jeszcze w latach dwudziestych XVII stulecia Maciej Kazimierz Sarbiewski wyjaśnił koncept: „niezgodna zgodność lub zgodna niezgodność". Przecież trudno, a może nawet niepodobna zaprzeczyć temu, że w swej jednostkowości dzieło literackie oraz w jej ogólności teoria literatury zarazem sa i nie sa samoistne. W Poetyce Tzvetana Todorova „Wszelkie dzieło [literackie - przyp. K.O.] jest więc rozpatrywane jedynie jako przejaw abstrakcyjnej i ogólnej struktury, której jest tylko jednym z możliwych urzeczywistnień” ${ }^{27}$. Treść i forma $w$ poezji wpisuje się w taką relację teorii i konkretu.

Niepodobna apriorycznie wykluczyć, że jedną z przyczyn przeoczenia aktu założycielskiego strukturalizmu immanentnego były przez Kleinera nieco szerzej podjęte w Treści i formie dwa romantyczne teksty: Konrad Wallenrod oraz Dziady. Z jednej strony anty-strukturalistyczne wyjaśnie-

${ }^{25}$, „[...] uczony genewski używa terminu »system« dla synchronicznego przekroju języka, a pojęcie struktury nie występuje w jego pracach. Kategoria ta została wprowadzona do językoznawstwa w badaniach praskiej szkoły strukturalnej. W ujęciu Nikołaja Trubieckiego struktura oznaczała sposób uporządkowania relacji w systemie fonologicznym. Z czasem pojęcie struktury zostało rozszerzone także na model stosunków w obrębie wypowiedzi”. Z. Mitosek, dz. cyt., s. 214.

${ }^{26}$ K. Polański, dz. cyt., s. 12.

${ }^{27}$ T. Todorov, Poetyka, tłum. S. Cichowicz, Warszawa 1984, s. 12. 
nie Kleinera: „Do wyraźniejszego oświetlenia [warstwowego - przyp. K.O.] schematu niechaj posłuży konstrukcja genezy Konrada Wallenroda"28. $\mathrm{Z}$ drugiej strony praktyka strukturalizmu immanentnego: dowiedzenie wariantywności przyjętych przez Mickiewicza form treści istotnej oraz (po części anty-psychogenetyczne) zastrzeżenie: „Dla konstrukcji [Konrada Wallenroda - przyp. K.O.] jednak pytanie, czy poeta naprawdę odczuwał możliwość różnych form, nie jest zasadnicze" ${ }^{29}$. Znamienne: siedemdziesiąt lat po Treści i formie w poezji, w 1991 roku, Edward Stankiewicz opublikuje rozprawę O synkretyzmie form $w$ „Konradzie Wallenrodzie”. W niej Kleiner pozostanie kimś po prostu nieobecnym ${ }^{30}$.

Treść $i$ forma $w$ poezji zawiera jeden bezdyskusyjny argument za przywołaniem Dziadów, tzn. rzeczowy:

Tam tylko trwa poczucie granicy [między treścią a formą - przyp. K.O.], gdzie utwór nie zaspokaja twórcy czy też jednostki percypującej: treść i forma różnią się w dziele, gdy są w rozdźwięku. Nie jest to bynajmniej cecha dzieł niewielkiej miary - przeciwnie, w największych właśnie tkwi często tragizm niewspółmierności formy i treści. Mickiewicz tę granicę czuł - w najpotężniejszym utworze. Konrad mówi o niej w wierszach wstępnych Improwizacji ${ }^{31}$.

Przychodzi stwierdzić: autor tekstu dla polskiego strukturalizmu immanentnego wręcz założycielskiego sam siebie przesłonił późniejszym przezeń krzewionym kultem romantycznych poetów. W świadomości pokoleń badaczy „Kleiner” wciąż nadal przeważnie znaczy 'Mickiewicz + Słowacki + Krasiński', co sprzyja zapoznaniu tego, że był ojcem założycielem strukturalizmu immanentnego.

Dla metodologicznej materii polskich badań literaturoznawczych Treść $i$ forma $w$ poezji to akt założycielski strukturalizmu immanentnego? - odpowiedź twierdząca jest w trybie koniecznym uwarunkowana kontekstem historycznym: 1922 rokiem. Należy więc poprzestać na chronologicznie pierwszym, poetologicznym nurcie literaturoznawczych badań strukturalnych i poniechać pytań o nurt semiotyczny oraz nurt narratologiczny (te

${ }^{28}$ J. Kleiner, Treść $i$ forma $w$ poezji..., s. 614.

${ }^{29}$ Tamże, s. 615, przyp. 12. Nawet psychogeneza nie przekreśla metody strukturalistycznej, por. T. Todorov, dz. cyt., s. 88-90.

${ }^{30},[\ldots]$ Konrad Wallenrod jest znakomitym osiagnięciem poetyckim Mickiewicza (i polskiego romantyzmu) nie tylko ze względu na swą oryginalność i głębię, ale także dzięki sposobowi, w jaki wszystkie aspekty tego dzieła - jego fabuła, gatunki literackie, kompozycja i wersyfikacja - zostały z sobą tak powiązane, by mogły stworzyć dzieło pełne napięć między formą a treścia, częściami a całością. E. Stankiewicz, O synkretyzmie form w „Konradzie Wallenrodzie”, przeł. I. Kalinowska-Blackwood, [w:] tegoż, Poetyka i sztuka słowa, Kraków 1966, s. 169.

${ }^{31}$ J. Kleiner, Treść i forma w poezji..., s. 611. 
trzy tu przywołane za Ryszardem Nyczem ${ }^{32}$ ). Jednak nawet poprzestawszy na owym poetologicznym nurcie, trudno oprzeć się wątpliwościom i bez zastrzeżeń orzec o tym, że Treść $i$ forma $w$ poezji to akt założycielski strukturalizmu immanentnego. Trudność jest uwarunkowana przede wszystkim rozumieniem samego strukturalizmu. Można ogólnie: „Mówiąc najprościej, strukturalizm oznacza poszukiwanie tego co wewnętrzne pod powłoką zewnętrzności, tego co systematyczne pod przypadkowym, tego co niezmienne pod zmiennym"33. Można precyzyjnie:

Zgodnie z tym ogólnym poglądem [na strukturalizm jako orientację badawczą w metodologii i teorii literatury XX wieku - przyp. K.O.] ukształtowały się typowe cechy metody strukturalnej, o charakterze zasadniczo antygenetycznym. Po pierwsze, przedmiotem badania jest tu utwór pojęty jako autonomiczna konstrukcja - a nie jako ekspresja podmiotu czy odbicie społecznej rzeczywistości - niezależnie więc od autorskiej intencji, sytuacji powstania dzieła czy pragmatyczno-historycznego kontekstu. Po drugie, celem badania jest opis strukturalnych cech (,literackości”, funkcji estetycznej czy poetyckiej) utworu, decydujacych o jego artystycznej integralności i literackim statusie - a nie procesu jego powstawania, przekazywanej treści czy niepowtarzalnych właściwości - przy uwzględnieniu powiązań z tekstami pokrewnymi, z którymi tworzy nadrzędna (rodzajowa, gatunkową itp.) systemową całość. Po trzecie, semantyka utworu ma charakter obiektywny (co znaczy: uprzedni i niezależny od interpretacyjnych czynności, a także stabilny, odznaczający się stałą naturą swych własności) oraz całościowy (wykraczający poza wartość sumy owych składników), co sprawia, że opis poszczególnych znaczeń wychodzić powinien od wiedzy o całościowej strukturze, odczytywanej z kolei na tle systemu (lub systemów), w którym (lub w których) jest realizowana ${ }^{34}$.

Przyjąwszy takie rozumienie strukturalizmu, niepodobna poprzestać na prostym orzekaniu, gdyż Treść i forma $w$ poezji nakazuje mówić nie o alternatywie „tak” bądź „nie”, lecz o ich koniunkcji i o proporcjach:

- Kleinera opis budowy dzieła literackiego z pewnością nie jest antygenetyczny, ale też niepodobna powiedzieć, że geneza oraz kontekst historyczny wyczerpuja podjęta przez niego materię;

- „treść” i „forma” dzieł literackich wręcz konstytuuja „literackość”;

- jeśli nie pierwsza, to przynajmniej druga część trzeciej „typowej cechy metody strukturalnej”, tzn. całościowy charakter, została uobecniona.

Zarazem należy podkreślić: Kleinera zaledwie dwustronicowa weryfikacja „teorii” warstw dzieła literackiego „praktyką” Konrada Wallenroda

${ }^{32}$ R. Nycz, Strukturalizm, teoria literatury i Edwarda Stankiewicza koncepcja poetyki, [w:] E. Stankiewicz, Poetyka i sztuka stowa, Kraków 1966, s. 11.

${ }^{33}$ E. Stankiewicz, Poetyka i sztuka słowa, przeł. J. Żukower-Narbuntowicz, T. Sławek, w: Poetyka i sztuka stowa..., s. 87.

${ }^{34}$ R. Nycz, dz. cyt., s. 9-10. 
była jedynie instrumentalna (,służebna”), tzn. uwarunkowana i jednocześnie ograniczona potrzeba ilustracji teoretycznoliterackiego wywodu i nie miała czegokolwiek z jakkolwiek rozumianej monografii problemowej bądź chociażby studium przypadku. Początek opisu tegoż poematu Mickiewicza pozostanie bezdyskusyjnie antystrukturalistyczny: „treść psychiczna, domagająca się wyrazu" oraz tytułowa postać jako wcielenie autora. Po czym możemy przeczytać:

Temat [poematu - przyp. K.O.] dopuszczał możliwości rozmaitego uksztaltowania na tle różnych rodzajów literackich: bohater mógł stać się ośrodkiem dramatu lub poematu epickiego; w zakresie epiki mógł być postacia epopei bohaterskiej w stylu homerowym - i te możliwość poeta tak wyraźnie odczuwał, że przynajmniej ustęp jeden ustylizował na epopeję (Powieść Wajdeloty); ale ówczesne zainteresowania literackie i pokrewieństwo tragicznego Wallenroda z tragicznymi jednostkami Byrona kazało wybrać formę poetyckiej powieści byrońskiej z pewnymi elementami powieści sensacyjnej i powieści walterskotowskiej; że jeszcze w obrębie tej formy istniała dla poety możliwość różnego układu treści, to rzecz wiadoma. Tak się ukształtowała ostatecznie struktura (warstwa C). Ustalona już treść zdobywa wreszcie formę wykończonego dzieła poetyckiego (warstwa D); jak silnie działał tu wybór możliwości różnych, świadczy wśród zmiennych typów opowiadania, dialogu i pieśni stosowanie wiersza epickiego i strofy lub nawet rytmów nierównomiernej długości. Ale chociaż analiza może nasunać pytanie, czy istotnie w stadiach poszczególnych nastapił wybór formy najwłaściwszej - utwór jest nierozerwalna jednościa, której treści niepodobna oddzielić od formy. W formie zmienionej - nie byłby dla nas Konradem Wallenrodem ${ }^{35}$.

Ten tu zacytowany passus przynajmniej mocno pobrzmiewa strukturalizmem i dlatego może być czytany jako początek drogi prowadzącej do Stankiewicza O synkretyzmie form $w$ „Konradzie Wallenrodzie”- publikacji wszak bezdyskusyjnie współtworzącej strukturalizm bez jakichkolwiek niedopowiedzeń sformułowany. Dla tegoż ,jednego z najwybitniejszych współcześnie polskich językoznawców" ${ }^{36}$ Treść i forma $w$ poezji pozostała nieobecna...

\section{BIBLIOGRAFIA}

Hutnikiewicz A., Stowo wstepne, [w:] J. Kleiner, W kręu historii i teorii literatury, wybór, oprac. A. Hutnikiewicz, Warszawa 1981.

Kleiner J., W kręgu historii i teorii literatury, wybór, oprac. A. Hutnikiewicz, Warszawa 1981.

${ }^{35}$ J. Kleiner, Treść i forma $w$ poezji..., s. 615-616; podkr. K.O.

${ }^{36}$ R. Nycz, dz. cyt., s. 7. 
Markiewicz H., Literaturoznawstwo i jego sqsiedztwa, Warszawa 1989.

Saussure F. de, Kurs językoznawstwa ogólnego, przekł. K. Kasprzyk, wstęp i przypisy K. Polański, Warszawa 2002.

Skwarczyńska S., Juliusz Kleiner jako metodolog i teoretyk literatury, [w:] Juliusz Kleiner. Księga zbiorowa o życiu i działalności, red. F. Araszkiewicz, Lublin 1961. Stankiewicz E., Poetyka i sztuka stowa, Kraków 1966.

Strukturalizm $w$ Europie środkowej $i$ wschodniej. Wizje i rewizje, red. D. Ulicka, W. Bolecki, Warszawa 2012.

Krzysztof Obremski - prof. zw. dr hab. (Wydział Humanistyczny UMK; Instytut Literaturoznawstwa, Katedra Antropologii Literatury i Nowych Mediów). Główne zakresy zainteresowań: 1) literatura polska i jej religijne wymiary (nie tylko staropolskie parafrazy Księgi Psalmów czy pisma Piotra Skargi); 2) literatura polska i jej polityczne uwarunkowania (szczególnie nowomowa). Redaktor książki Marcin Luter 1517-2017 (2019). Współwydawca toruńskich wierszy weselnych i zagadek przełomu XVII/XVIII stulecia (w druku). ORCID: 0000-0001-6164-9207. E-mail: <obremski@umk.pl>.

Krzysztof Obremski - professor, PhD (dr hab.) (Faculty of Humanities, Nicolas Copernicus University; Institute of Literary Studies, Department of Anthropology of Literature and New Media). Main areas of interest: 1) Polish literature and its religious dimensions (not only Old Polish paraphrases of the Book of Psalms or the writings of Piotr Skarga); 2) Polish literature and its political conditionality (especially newspeak). Editor of the book Martin Luther 1517-2017 (2019). Co-editor of Torun Wedding Poems and Riddles of the Turn of the 17th/18th Century (in print). ORCID: 0000-0001-61649207. E-mail: <obremski@umk.pl>. 
